\title{
Adolescent friendly health services: perceptions and practice of medical professionals
}

\author{
Sujindra E.*, Bupathy A.
}

Department of Obstetrics and Gynecology, Indira Gandhi Medical College and Research Institute, Puducherry, India

Received: 23 July 2016

Accepted: 16 August 2016

\section{*Correspondence:}

Dr. Sujindra E.,

E-mail: sujindra@rediffmail.com

Copyright: ( ) the author(s), publisher and licensee Medip Academy. This is an open-access article distributed under the terms of the Creative Commons Attribution Non-Commercial License, which permits unrestricted non-commercial use, distribution, and reproduction in any medium, provided the original work is properly cited.

\section{ABSTRACT}

Background: Introduction Adolescence is a period of intricacies, with a wide range of adolescent health problems, such as depression, eating disorders, drug and alcohol use, unplanned pregnancy, chronic illness, and suicide due to unfavorable social conditions and risk taking behaviors. Not many studies are there to assess problems related to providing health services to adolescents. Our study analyzed the views about perception and practice of adolescent health among doctors of the different groups of medical discipline.

Methods: A total of 44 doctors, 12 from ayurveda, 10 from siddha, 10 from homeopathy and 12 from allopathy, were included in the study who filled in questionnaire containing 17 questions on perceptions and practice of adolescent health.

Results: Response rate was $100 \%$. Overall the doctors understanding on adolescent health was good. Majority of the doctors $(90 \%)$ felt that adolescents are not comfortable in the present available setting to bring out their problems. Only 3 of our doctors had received formal training in adolescent health and are informed about adolescent friendly health services. There was no separate forum to render adolescent health services.

Conclusions: Effectively planning, implementation and also evaluation of health programs in adolescent health is required to change attitude of adolescents, the health providers and also that of the setting where adolescents are addressed. Health professionals have their credibility towards adolescents, and the advice they give may be important for teenage behavior.

Keywords: Adolescence, Health services, Perceptions, Practice

\section{INTRODUCTION}

The term adolescence is referred to the lifespan between 10 to 19 years. This is a period of rapid changes in body size, physiological, psychological and social functioning. ${ }^{1}$ This phase is commonly thought of as a period of optimum health. But in the present day scenario, there is an increase in a range of adolescent health problems, such as depression, eating disorders, drug and alcohol use, unplanned pregnancy, chronic illness, and suicide due to unfavorable social conditions and adaptive nature of adolescents to unhealthy and risk taking behaviors. ${ }^{2,3}$ The consequence of health problem in adolescents does not restrict itself to this age category. Rather it persists and shows its effect on their future life. Many studies confirm that many health problems and risky behavior in adulthood have their start during adolescence and hence there is a need to improve the accessibility and quality of health services to adolescents. ${ }^{4}$

Despite international consensus regarding adolescents' right to reproductive health services and information, adolescents face many barriers to accessing services. ${ }^{5,6} \mathrm{~A}$ number of organizations have sought to provide adolescent friendly services to improve access to health care. $^{7,8}$ The National Adolescent health strategy was initiated in 2014 by the Ministry of Health \& Family Welfare under the name of Rashtriya Kishor Swasthya Karyakram (RKSK), for children in the age group of 1019 years, which would target their nutrition, reproductive 
health and substance abuse, among other issues. This strategy realigns the existing clinic-based curative approach to focus on a more holistic model based on a continuum of care for adolescent health and developmental needs.

In the Australian healthcare system general practitioners provide the most accessible primary health care for adolescents. ${ }^{9}$ Evidence based strategies in helping doctors learn and change practice are at the forefront of the design of continuing medical education. Hence this study was conducted to target the general practitioners, not only belonging to allopathic branch but also those who practice in ayurveda, siddha and homeopathy. The study analyzed the views about perception and practice of adolescent health among doctors of the different groups of medical profession.

\section{METHODS}

To identify the knowledge, perception and skill of medical professionals working at primary and community health centers, a training program was conducted under the authority of RKSK in the union territory of Puducherry. The program was attended by medical officers in the specialty of ayurveda, siddha and homeopathy from primary and community health center. All these doctors were included in the study after their consent. Similarly doctors of the allopathic division working in primary and community health center were also included. It was a cross-sectional descriptive study to analyze the perceptions and practices about adolescent health.

Participation to the study was on voluntary basis. All participants were assured of anonymity and confidentiality of responses. Data was collected using a self-administered close-ended questionnaire. The questionnaire comprised of 17 questions (10 questions on perceptions and 7 practices).

\section{RESULTS}

The study involved a cohort of 44 doctors from different discipline of medicine. 12 doctors from Ayurveda, 10 from Siddha, 10 from homeopathy and 12 from Allopathy. All completed the questionnaire and the response rate was $100 \%$. Perceptions about adolescent health among doctors are shown in Table 1. In this session doctors were put forth ten questions on their perceptions towards adolescent hood, their thoughts and experiences on adolescent health seeking behaviors and their training and ideas towards establishing adolescent friendly health services. The numbers are shown in Table 1. Overall the doctors understanding on adolescent health was good. Majority of the doctors $(90 \%)$ felt that adolescents are not comfortable in the present available setting to bring out their problems; the main reasons being lack of privacy and lack of knowledge. $85 \%$ of doctors felt that adolescents should be informed adequately about sexual and reproductive health. Only 3 of our doctors had received formal training in adolescent health and are informed about adolescent friendly health services.

Issues relating to practices on adolescent health among doctors are shown in Table 2. All our doctors have encountered adolescents in their practice, however only a few of them have addressed adolescents in a separate forum, given them adequate attention and answered all their questions. Only one doctor accepted that she discusses about contraception with adolescents freely. Almost all doctors identified nutritional deficiency, menstrual problems, sexual violence and mental illness as health related concerns of adolescents in their work area.

\section{DISCUSSION}

UNICEF has defined adolescence as "the sequence of events by which the individual is transformed into a young adult by a series of biological changes". "True to the literal meaning of the term (the Greek word, adolescere denotes "to grow and to mature"), the sentinel occurrence during the period of adolescence is, "rapid growth", not just physical and biological (sexual) but also emotional, cognitive, psychological and social.

A considerable proportion of adolescents, both boys and girls, face challenges to their healthy development into adulthood due to a variety of factors including structural poverty, lack of information, unfavorable social norms, missed opportunity of education, lack of vocational training, societal expectations of early marriage, childbearing, and forceful parenting.

In our study we analyzed the perceptions and practices of doctors from different discipline at primary and community health centers. These are the places adolescents would present more due to easy accessibility. Our study revealed that there were lots of barriers to adolescents for proper access to health services. Further our doctors were not specially qualified to tackle them and also most often a separate forum to address these issues was not available. Veit surveyed 1000 Victorian general practitioners and found that $80 \%$ reported inadequate undergraduate training in consultation skills and psychosocial diseases in adolescents and $87 \%$ wanted continuing medical education in these areas. ${ }^{3}$ Previous studies have also showed consultations with teenagers are shorter than for other age groups. ${ }^{10}$

In 2009, adolescents accounted for $18 \%$ of the world population, with a majority of them $(88 \%)$ lived in developing countries. ${ }^{10}$ India's Adolescents population is 253 million (22\% of total population) and highest in the world. Studies show that investing in the health of adolescents prevents the estimated 1.4 million deaths that occur globally every year. ${ }^{10}$ Earlier studies have also pointed towards concerns about confidentiality, discomfort in disclosing health issues, absence of 
adequate counseling services and difficulty in accessing services as some of the health related barriers identified by adolescents. Thus an intensified effort is required to increase health service utilization of adolescents especially on reproductive health service. ${ }^{11}$ Adolescent childbearing is associated with negative health outcomes for both the adolescent mother and the infant. ${ }^{10,13}$ Adolescents should be addressed in an atmosphere of trust and confidentiality. ${ }^{12}$ Health care providers should value the privacy of adolescents and always restrain themselves from judgmental attitudes.

Table 1: Perceptions about adolescent health among doctors.

\begin{tabular}{|c|c|c|c|c|c|}
\hline $\begin{array}{l}\text { Q. } \\
\text { No. }\end{array}$ & Question & $\begin{array}{l}\text { Ayurveda } \\
(\mathrm{n}=12)\end{array}$ & $\begin{array}{l}\text { Siddha } \\
(\mathrm{n}=10)\end{array}$ & $\begin{array}{l}\text { Homeopathy } \\
(\mathrm{n}=10)\end{array}$ & $\begin{array}{l}\text { Allopathy } \\
(\mathrm{n}=12)\end{array}$ \\
\hline \multirow{4}{*}{1.} & Adolescents are different from children or adults & & & & \\
\hline & Physically & 1 & 0 & & \\
\hline & Mentally & 2 & 2 & & \\
\hline & Both & 9 & 8 & 10 & 12 \\
\hline \multirow[b]{2}{*}{2.} & Is adolescent health important & & & & \\
\hline & $\begin{array}{l}\text { Yes } \\
\text { No }\end{array}$ & 12 & 10 & 10 & 12 \\
\hline \multirow{3}{*}{3.} & $\begin{array}{l}\text { How do you think an adolescent feels when he/she walks } \\
\text { into your health centre? }\end{array}$ & & & & \\
\hline & Shy/Embarrassed & 7 & 6 & 7 & 8 \\
\hline & $\begin{array}{l}\text { Fearful } \\
\text { Confident }\end{array}$ & 5 & 4 & 3 & 4 \\
\hline \multirow[t]{3}{*}{4.} & $\begin{array}{l}\text { Do you feel adolescent are comfortable in the present } \\
\text { available } \\
\text { setting to bring out their problems }\end{array}$ & & & & \\
\hline & Yes & 2 & & 1 & \\
\hline & No & 10 & 10 & 9 & 12 \\
\hline \multirow{4}{*}{5.} & $\begin{array}{l}\text { What are barriers to adolescents for good } \\
\text { communication? }\end{array}$ & & & & \\
\hline & Lack of privacy & 10 & 7 & 6 & 6 \\
\hline & Lack of knowledge & 2 & 3 & 4 & 5 \\
\hline & Lack of confidence in health provider & & & & 1 \\
\hline \multirow{3}{*}{6.} & $\begin{array}{l}\text { Do adolescents need to be informed about sexual and } \\
\text { reproductive health }\end{array}$ & & & & \\
\hline & Yes & 9 & 8 & 8 & \\
\hline & No & 3 & 2 & 2 & 12 \\
\hline \multirow{3}{*}{7.} & $\begin{array}{l}\text { Have you heard of Adolescent Friendly Health Services } \\
\text { earlier }\end{array}$ & & & & \\
\hline & Yes & & & 1 & 2 \\
\hline & No & 12 & 10 & 9 & 10 \\
\hline \multirow{3}{*}{8.} & Have you been trained in adolescent health earlier? Yes & & & & \\
\hline & & & & 1 & 2 \\
\hline & No & 12 & 10 & 9 & 10 \\
\hline \multirow{5}{*}{9.} & $\begin{array}{l}\text { How health system can help adolescents to } \\
\text { attain optimum health? }\end{array}$ & & & & \\
\hline & Adolescent education & 6 & 8 & 5 & 5 \\
\hline & Education of parents, teachers peers & 4 & & 2 & 3 \\
\hline & Adolescent Friendly Health Services & & & 1 & 2 \\
\hline & Mass media & 2 & 2 & 2 & 2 \\
\hline \multirow[t]{2}{*}{10.} & $\begin{array}{l}\text { Do you think the government's objective of introducing } \\
\text { separate program for adolescent health is correct } \\
\text { Yes }\end{array}$ & & & & \\
\hline & No & 12 & 10 & 10 & 12 \\
\hline
\end{tabular}


Table 2: Practices on adolescent health among doctors.

\begin{tabular}{|c|c|c|c|c|c|}
\hline Q. No. & Question & $\begin{array}{l}\text { Ayurveda } \\
(\mathrm{n}=12)\end{array}$ & $\begin{array}{l}\text { Siddha } \\
(n=10)\end{array}$ & $\begin{array}{l}\text { Homeopathy } \\
(\mathbf{n}=\mathbf{1 0})\end{array}$ & $\begin{array}{l}\text { Allopathy } \\
(\mathrm{n}=12)\end{array}$ \\
\hline 1. & $\begin{array}{l}\text { Have you encountered adolescents in your clinic earlier } \\
\text { Yes } \\
\text { No }\end{array}$ & 12 & 10 & 10 & 12 \\
\hline 2. & $\begin{array}{l}\text { Do adolescents in your locality approach you easily } \\
\text { Yes } \\
\text { No }\end{array}$ & $\begin{array}{l}3 \\
9\end{array}$ & $\begin{array}{l}2 \\
8\end{array}$ & $\begin{array}{l}4 \\
6\end{array}$ & $\begin{array}{l}4 \\
8\end{array}$ \\
\hline 3. & $\begin{array}{l}\text { Have you given separate attention to adolescents earlier } \\
\text { Yes } \\
\text { No }\end{array}$ & $\begin{array}{l}2 \\
10\end{array}$ & $\begin{array}{l}3 \\
7\end{array}$ & $\begin{array}{l}4 \\
6\end{array}$ & $\begin{array}{l}4 \\
8\end{array}$ \\
\hline 4. & $\begin{array}{l}\text { Do you have a separate forum to assess adolescent heath } \\
\text { in your set up } \\
\text { Yes } \\
\text { No }\end{array}$ & 12 & 10 & $\begin{array}{l}2 \\
8\end{array}$ & 12 \\
\hline 5. & $\begin{array}{l}\text { Have you answered all questions of adolescents } \\
\text { Yes } \\
\text { No }\end{array}$ & $\begin{array}{l}1 \\
11\end{array}$ & 10 & 10 & 12 \\
\hline 6. & $\begin{array}{l}\text { Do you discuss about contraception to adolescents } \\
\text { freely } \\
\text { Yes } \\
\text { No }\end{array}$ & 12 & 10 & 10 & $\begin{array}{l}1 \\
11\end{array}$ \\
\hline 7. & $\begin{array}{l}\text { What are the health related concerns of adolescents in } \\
\text { your work area? } \\
\text { Nutritional deficiency } \\
\text { Menstrual problems } \\
\text { Sexual violence } \\
\text { Mental illness } \\
\text { All }\end{array}$ & 11 & 10 & 10 & 12 \\
\hline
\end{tabular}

Thus we conclude that effectively planning, implementation and also evaluation of health programs in adolescent health is required to change attitude of adolescents, the health providers and also that of the setting where adolescents are addressed. The RKSK program launched on 7th January, 2014 with the key principles of enabling all adolescents in India to realize their full potential is expected to go a great way to realize these ideals.

\section{CONCLUSION}

Health professionals have their credibility towards adolescents, and the advice they give may be important for teenage behaviour. Our study helped to identify the gap in training so that evidence based educational intervention can be designed to improve the knowledge, skill, and self perceived competency of Medical professionals in adolescent health.

\section{Funding: No funding sources}

Conflict of interest: None declared

Ethical approval: The study was approved by the Institutional Ethics Committee

\section{REFERENCES}

1. UNICEF. The state of the world's children: adolescence an age of opportunity. 2011.

2. Ginsburg KR, Slap GB. Unique needs of the teen in the health care setting. Curr Opin Pediatr. 1996;8:333-7.

3. Veit FCM, Sanci LA, Young DYL, Bowes G. Adolescent health care: perspectives of Victorian general practitioners. Med J Aust. 1995;163:16-8.

4. Bearinger LH, Gephart J. Interdisciplinary education in adolescent health. J Paediatr Child Health. 1993;29:10-5S.

5. Wood K, Maepa J, Jewkes R. Adolescent Sex and Contraceptive Experiences: Perspectives of Teenagers and Clinic Nurses in the Northern Province. South Africa: Health Systems Trust. 1998.

6. Zielinski GE, Magnani R. Who Can We Trust With Our Problems: Barriers to Adolescent Use of Reproductive Health Services in Three Bolivian Cities. Washington, DC: Focus on Young Adults Program/Pathfinder International. 2001.

7. Glover EK, Erulker AS, Nerquaye-Tetteh J. Youth Centres in Ghana: Assessment of the Planned 
Parenthood Association of Ghana Program. New York: Population Council. 1998.

8. Mari MK, Magnani R. Does making clinic-based reproductive health services more youth friendly increase service use by adolescents? Evidence from Lusaka, Zambia. J Adolesc Health. 2003;33:259-70.

9. Bennett DL. Adolescent health in Australia: an overview of needs and approaches to care. Sydney: Australian Medical Association. 1984.

10. Jacobson LD, Wilkinson C, Owen PA. Is the potential of teenage consultations being missed? A study of consultation times in primary care. Fam Pract. 1994;11:296-9.

11. WHO. Strengthen the health sector response to adolescents' health and development. Department of child and adolescent health and development. 20 avenues APPIA, 1211 Geneva, Switzerland. 2009.

12. Hoover KW, Guoyu Tao, Berman S. Utilization of health services in physician offices and outpatient clinics by adolescents and young women in the United States: Implications for improving access to reproductive health services. Journal of adolescent health. 2010;46:324-30.

13. Walker ZAK, Townsend JL, Bell J, Marshall S. An opportunity for teenage health promotion in general practice: an assessment of current provision and needs. Health Educ J. 1999;58:218-27.

14. Britto MT, Tivorsak TL, Slap GB. Adolescents' needs for health care privacy. USA. Pediatrics. 2010;126(6):e1469-76.

Cite this article as: Sujindra E, Bupathy A. Adolescent friendly health services: perceptions and practice of medical professionals. Int J Reprod Contracept Obstet Gynecol 2016;5:2968-72. 